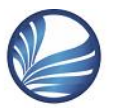

ELK

Asia Pacific Journals

Www.elkjournals.com

\title{
IMPACT OF BASEL III IMPLEMENTATION ON UAE BANKS: PROFITABILITY AND LOAN PRICING
}

\section{Dr. Yousef Padganeh}

Senior Executive Banker and

IAU visiting professor

Email:

Yousefpadganeh.1@gmail.com

Professor Mohammad Mehdi
Osku Nejad
Dean of Business School, IAU,
Dubai, UAE.
Email: oskounejad@iau.ae

Nayyereh Jafar Asl

Master of Accountancy Student

at IAU, Dubai, UAE.

Email:

nayyerehjafariasl@gmail.com

\begin{abstract}
The purpose of this research is to analyze the impact of Basel III implementation on UAE banks. More specifically, the research aim is to uncover the impact on Loan Pricing, and profitability by seeking risk professional opinion and analyzing banks published financial statements. The result of research shows that, implementation of Basel III will lead to a higher loan pricing, and decrease profitability. Basel III is the most recent version of the Basel global standards for bank regulation, adopted in response to the 2007/2008 financial crisis. Basel III is a global regulatory standard on bank capital adequacy and liquidity risk published by Basel Committee on Banking Supervision in 2010.
\end{abstract}

Keywords: Bank, Basel, Capital, Loan, Pricing, Provisioning, UAE

\section{1) Introduction}

The Basel III proposal was released in December 2010 and is a result of amendments to two consultative documents published in the end of 2009. Basel III does not properly address the most fundamental regulatory problem that the 'promises' that make up any financial system are not treated equally
(Wignall .A.B., Atkinson. P, 2010). For more than two decades, the Bank for International Settlements develops guidelines to improve the financial stability of the financial sector and the real economy. According to Cosimano and Hakura (2011), large banks would on average need to increase their equityto-asset ratio by 1.3 percentage points 
under the Basel III framework. Slovik and Cournède (2011) estimated that, the medium-term impact of Basel III implementation on GDP growth is in the range of -.0 .0 to -0.15 percentage point per annum. Economic output is, mainly affected by an increase in bank lending spreads as banks pass a rise in bank funding costs, due to higher capital requirements, to their customers.

Basel III was introduced to address the shortfall in the financial sector that led to the global financial crisis (Al-Tamimi, 2012)

Basel III Adherence to the Basel III capital adequacy norms has again posed new challenges for the banks to make necessary adjustments in their capital base (Roy, 2014).

The resultant capital adequacy framework is termed "Basel III" and the G20 endorsed the new Basel capital and liquidity requirements as heir November
2010 summit in Seoul. (KPMG 2011). According to BCBS179 (2010), the Committee's package of reforms will increase the minimum common equity requirement from $2 \%$ to $4.5 \%$ by 2015 .In addition, banks will be required to hold a capital conservation buffer of $2.5 \%$ to withstand future periods of stress bringing the total common equity requirements to $7 \%$. This reinforces the stronger definition of capital agreed by governors and heads of supervision in July 2010 and the higher capital requirements for trading, derivatives and securitisation activities to be introduced at the end of 2011 as agreed. Below table extracted from Basel committee) shows time plan implementation of Basel III framework. Most of the banks are working hard to not to face any problem in implementing the new standards. This needs a lot of time and expenses.

We find this interesting to study the new Basel framework and how it might 
impact UAE banks. The topic is highly interesting and of current interest for the banks and for most of its stakeholders. Notably, financial institutions are particularly interested in determining the effects of the new framework as dealing with regulatory uncertainty is a considerable concern among bank managers. The main problem is the bankers are not clear with the level of impact on their profitability and Loan Pricing. UAE banks enjoy a high capital ratio based on the Basel II regime but there is no impact analysis to see the shock of Basel III.

The UAE banking system is stable and has a high level of adequacy with high capital and liquidity, "The UAE will be applying Basel III gradually until the year 2019 and the UAE banks have no problem if Basel III is applied as they have high liquidity, no cash problems and their capital are already high,".( Al Suwaidi. 2012).

According to Gulfnews (2014), Basel III capital requirements present an opportunity for Middle East banks and regulators to embrace new rules and improve the sector's asset quality and risk-return profiles, according to a study by management consultancy Strategy\&, formerly Booz \& Company.

The study, which analyses the ability of a sample of 22 banks in the Gulf Cooperation Council (GCC) and the Levant to meet BASEL III capital requirements, said regional banks which do not address the new capital requirements will find themselves with capital adequacy ratios ranging from shortfalls of -10.4 per cent to excesses of +10.5 per cent of Basel III minimums The study shows that some of the banks could face up to 25 per cent of total regulatory capital required by 2019 as per Basel III rules, assuming current 


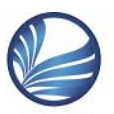

ELK

Asia Pacific Journals

www.elkjournals.com

growth rates.

The key question of this research is:

Does the implementation of Basel III recommendation affect the profitability and loan pricing on UAE Banks?

\section{2) Research Objectives}

The objectives of this research are:

a) To analyze the impact of Basel III banks' profitability; and

b) To demonstrate the impact of Basel III on loan pricing.

3) Research Methodology and Approach

a) Research Population and Sampling Method

To determine the sample, we used Morgan table in this research. In a bestcase scenario, a maximum number of 160 risk professionals are currently working in Basel standard implementation area in the UAE. Based on confidence level of $95 \%$ and assuming error of $5 \%$ a total number of
113 risk professionals across the banking system targeted. The target population was, 160 risk professionals working from the UAE banking system.

\section{b) Data Collection}

We used qualitative and quantitative approaches in this research. A questionnaire was mailed / handed over (two GARP meetings) to 109 selected risk professionals for the study, accompanied by a cover letter. Recipients were requested to complete the questionnaire and to return it by email. In addition to the questionnaire, a full review of financial statements of UAE local bank have been performed. Both primary and secondary data have been collected in this research.

\section{c) Reliability Test}

Inter item consistency is measured by using reliability. Crohnbach's alpha is the measure of reliability which ranges from 0 to 1 , where 0 indicates the no 


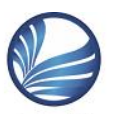

ELK

Asia Pacific Journals

Www.elkjournals.com

consistency and more than 0.6 indicating

the acceptable consistency.

Cronbach's alpha is the average value of the reliability co-efficient where one could obtain for all possible combinations of items. Cronbach's Alpha is calculated for internal consistency reliability. Risk professionals were asked to responds to the statement using a five point Likert Scale ranging from 1 Strongly Agree to 5 Strongly disagree. Cronbach's Alpha reliability co-efficient normally ranges between 0 and 1 however; there are actually no lower limit to the co-efficient (Table 1). The closer Cronbach's Alpha co-efficient is to 1.00 the greater the internal consistency of the items in the scale. Cronbach's Alpha is calculated by following formula:

Cronbcah's Alpha $=\mathrm{rk} /[1+(\mathrm{k}-1) \mathrm{r}]$
Where; a) $\mathrm{k}=$ number of items considered, and b) $r=$ the mean of the inter-item correlations.

\begin{tabular}{|c|c|l|}
\hline Rank & $\begin{array}{c}\text { Cronbach's } \\
\text { alpha }\end{array}$ & \multicolumn{1}{|c|}{$\begin{array}{c}\text { Internal } \\
\text { consistency }\end{array}$} \\
\hline 1 & $\alpha \geq 0.9$ & $\begin{array}{l}\text { Excellent (High- } \\
\text { Stakes testing) }\end{array}$ \\
\hline 2 & $0.7 \leq \alpha<0.9$ & $\begin{array}{l}\text { Good (Low- } \\
\text { Stakes testing) }\end{array}$ \\
\hline 3 & $0.6 \leq \alpha<0.7$ & Acceptable \\
\hline 4 & $0.5 \leq \alpha<0.6$ & Poor \\
\hline 5 & $\alpha<0.5$ & Unacceptable \\
\hline
\end{tabular}

Table 1: Cronbach's alpha I - Source: Cortina, J.M. (1993).

The crohnabach's alpha was 0.687 which is deemed to be acceptable (Table 2).

\begin{tabular}{|c|c|}
\hline Particulars & $\begin{array}{c}\text { Crohnbach's alpha } \\
(\boldsymbol{\alpha})\end{array}$ \\
\hline Overall & 0.69 \\
\hline
\end{tabular}

Table 2: Cronbach's alpha II

\section{d) Validity Test}

The factor analysis is a data reduction method where the items are force to form a single factor. When items determining Basel III regulatory standards were 


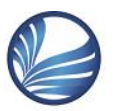

ELK

Asia Pacific Journals

www.elkjournals.com

reduced by using factor analysis, was able to explain $74.17 \%$ of the variance (Table 3). The factor loadings of all the items of the analysis were more than 0.4 proving the discriminant and convergent validity. Hence, all the items could be considered for further analysis.

\begin{tabular}{|l|c|}
\hline \multicolumn{1}{|c|}{ Items } & Factor loadings \\
\hline $\begin{array}{l}\text { Through Basel III } \\
\text { regulatory standards, } \\
\text { banks may be able to } \\
\text { increase the weighted } \\
\text { average cost of capital. }\end{array}$ & .788 \\
\hline $\begin{array}{l}\text { Basel III regulatory } \\
\text { standards create upright } \\
\text { impact on the loan } \\
\text { pricing. }\end{array}$ & .780 \\
\hline $\begin{array}{l}\text { Basel III regulatory } \\
\text { standards offer essential } \\
\text { arithmetic to compute } \\
\text { incremental effects of } \\
\text { loan pricing. }\end{array}$ & .766 \\
\hline $\begin{array}{l}\text { Basel III regulatory } \\
\text { standards offer various } \\
\text { standards and } \\
\text { assumptions regarding } \\
\text { loan pricing. }\end{array}$ & \\
\hline $\begin{array}{l}\text { Basel III regulatory } \\
\text { standards lead to a better }\end{array}$ & .597 \\
\hline
\end{tabular}

Funds Transfer Pricing (FTP) mechanism.

Table 3: Validity

Morgan approach used to define sample of study using conditional level of $95 \%$ and assuming an error of 5\%. Total number of 113 risk professionals were targeted across the banking system in which 109 completed the questionnaire. Several ways of sending questionnaire such as email direct handover and risk professional chapter attending and direct distributing used to collect the data. To ensure data are valid and reliable Corhnbach's test performed and result is acceptable.

\section{e) Limitations of the Study}

Although the research has reached its aims, there were some unavoidable limitations such as; time limit, cost, banker's unavailability and lack of strong knowledge of Basel III standards

\section{4) Research Hypothesis}


Asia Pacific Journals

In line with the research objectives, two hypotheses been made and all will be tested by using ANOVA (Table 4).

\begin{tabular}{|c|c|}
\hline HI & $\begin{array}{l}\text { Ho: Basel III regulation will not } \\
\text { decrease banks' profitability in } \\
\text { UAE. } \\
\text { HA: Basel III regulations will }_{\text {A }} \\
\text { decrease banks' profitability in } \\
\text { UAE. }\end{array}$ \\
\hline HII & $\begin{array}{l}\mathbf{H}_{0:} \text { Basel III regulation will not } \\
\text { lead to a higher loan pricing in } \\
\text { UAE. } \\
\text { HA: Basel III regulation will }_{\mathrm{A}} \\
\text { lead to a higher loan pricing in } \\
\text { UAE. }\end{array}$ \\
\hline
\end{tabular}

Table 4. Hypotheses $-\mathrm{H}_{0}=$ Null Hypotheses $\quad \mathbf{H}_{\mathbf{A}}=$ Alternative Hypotheses

\section{5) Data Analysis and Hypotheses testing}

a) Bivariate statistics

From the following table we can observe that the mean value of the loan provision, profitability and high loan pricing was high in $31-40$ years of age group. The mean value of banks capital was high in $21-30$ years of age group (Table 5).

\begin{tabular}{|c|c|c|c|}
\hline \multicolumn{2}{|c|}{ Age } & \multirow{2}{*}{\begin{tabular}{|c|} 
Profitability \\
3.3333 \\
\end{tabular}} & \multirow{2}{*}{$\begin{array}{c}\begin{array}{c}\text { Loan } \\
\text { pricing }\end{array} \\
2.9524\end{array}$} \\
\hline \multirow{3}{*}{$\begin{array}{c}21-30 \\
\text { years }\end{array}$} & Mean & & \\
\hline & $\mathrm{N}$ & 21 & 21 \\
\hline & $\begin{array}{c}\text { Std. } \\
\text { Deviation }\end{array}$ & .38188 & .59487 \\
\hline \multirow{3}{*}{$\begin{array}{c}31-40 \\
\text { years }\end{array}$} & Mean & 3.3773 & 3.0955 \\
\hline & $\mathrm{N}$ & 55 & 55 \\
\hline & $\begin{array}{c}\text { Std. } \\
\text { Deviation }\end{array}$ & .44062 & .53249 \\
\hline \multirow{3}{*}{$\begin{array}{c}41-50 \\
\text { years }\end{array}$} & Mean & 3.3750 & 3.1518 \\
\hline & $\mathrm{N}$ & 28 & 28 \\
\hline & $\begin{array}{c}\text { Std. } \\
\text { Deviation }\end{array}$ & .43833 & .53722 \\
\hline \multirow{3}{*}{$\begin{array}{c}51-60 \\
\text { years }\end{array}$} & Mean & 3.4500 & 3.1000 \\
\hline & $\mathrm{N}$ & 5 & 5 \\
\hline & $\begin{array}{c}\text { Std. } \\
\text { Deviation }\end{array}$ & .48088 & .54772 \\
\hline \multirow{3}{*}{ Total } & Mean & 3.3716 & 3.0826 \\
\hline & $\mathrm{N}$ & 109 & 109 \\
\hline & $\begin{array}{c}\text { Std. } \\
\text { Deviation }\end{array}$ & .42575 & .54333 \\
\hline
\end{tabular}

Table 5: Profitability and Loan Pricing Vs. Age 
Asia Pacific Journals

$\underline{\text { www.elkjournals.com }}$

From the following table we can observe that the mean value of loan provision, profitability, loan pricing and banks capital was high in males (Table 6).

\begin{tabular}{|c|c|c|c|}
\hline \multicolumn{2}{|c|}{ Gender } & Profitability & Loan pricing \\
\hline \multirow{4}{*}{ F } & Mean & 3.1875 & 2.9750 \\
\cline { 2 - 4 } & $\mathrm{N}$ & 20 & 20 \\
\cline { 2 - 4 } & $\begin{array}{c}\text { Std. } \\
\text { Deviation }\end{array}$ & .30213 & .49271 \\
\hline \multirow{4}{*}{ M } & Mean & 3.4129 & 3.1067 \\
\cline { 2 - 4 } & $\mathrm{N}$ & 89 & 89 \\
\cline { 2 - 4 } & $\begin{array}{c}\text { Std. } \\
\text { Deviation }\end{array}$ & .43969 & .55377 \\
\hline \multirow{3}{*}{ Total } & \begin{tabular}{c} 
Mean \\
\cline { 2 - 4 }
\end{tabular} & 3.3716 & 3.0826 \\
\cline { 2 - 4 } & N & 109 & 109 \\
\hline & $\begin{array}{c}\text { Std. } \\
\text { Deviation }\end{array}$ & .42575 & .54333 \\
\hline
\end{tabular}

Table 6: Profitability and Loan Pricing Vs Gender

From the following table we can observe that the mean value of loan provision, profitability, loan pricing and banks capital was high in for undergraduates than others (Table 7).

\begin{tabular}{|c|c|c|c|}
\hline \multicolumn{2}{|c|}{ Educational Qualification } & \multirow{2}{*}{\begin{tabular}{|c|}
$\begin{array}{c}\text { Profitabili } \\
\text { ty }\end{array}$ \\
3.4524
\end{tabular}} & \multirow{2}{*}{$\begin{array}{c}\begin{array}{c}\text { Loan } \\
\text { pricin } \\
\mathrm{g}\end{array} \\
\begin{array}{c}3.071 \\
4\end{array}\end{array}$} \\
\hline \multirow{3}{*}{ GRADUATE } & Mean & & \\
\hline & $\mathrm{N}$ & 21 & 21 \\
\hline & $\begin{array}{c}\text { Std. } \\
\text { Deviati } \\
\text { on }\end{array}$ & .48489 & $\begin{array}{c}.5708 \\
7\end{array}$ \\
\hline \multirow{3}{*}{$\begin{array}{c}\text { POST } \\
\text { GRADUATE }\end{array}$} & Mean & 3.3125 & $\begin{array}{c}3.125 \\
0\end{array}$ \\
\hline & $\mathrm{N}$ & 36 & 36 \\
\hline & $\begin{array}{c}\text { Std. } \\
\text { Deviati } \\
\text { on }\end{array}$ & .40697 & $\begin{array}{c}.5622 \\
0\end{array}$ \\
\hline \multirow{3}{*}{$\begin{array}{l}\text { PROFISSIONAL } \\
\text { CERTIFICATES }\end{array}$} & Mean & 3.3375 & $\begin{array}{c}3.012 \\
5\end{array}$ \\
\hline & $\mathrm{N}$ & 40 & 40 \\
\hline & $\begin{array}{c}\text { Std. } \\
\text { Deviati } \\
\text { on }\end{array}$ & .36493 & $\begin{array}{c}.5369 \\
4\end{array}$ \\
\hline \multirow{3}{*}{$\begin{array}{l}\text { UNDERGRADU } \\
\text { ATE }\end{array}$} & Mean & 3.5208 & $\begin{array}{c}3.208 \\
3\end{array}$ \\
\hline & $\mathrm{N}$ & 12 & 12 \\
\hline & $\begin{array}{c}\text { Std. } \\
\text { Deviati } \\
\text { on }\end{array}$ & .54833 & $\begin{array}{c}.4865 \\
6\end{array}$ \\
\hline
\end{tabular}


Asia Pacific Journals

Www.elkjournals.com

\begin{tabular}{|c|c|c|c|}
\hline \multirow{4}{*}{ Total } & Mean & 3.3716 & 3.082 \\
6 & $\mathrm{~N}$ & 109 & 109 \\
\cline { 2 - 4 } & $\begin{array}{c}\text { Std. } \\
\text { Deviati } \\
\text { on }\end{array}$ & .42575 & .5433 \\
& & 3 \\
\hline
\end{tabular}

Table 7: Profitability and Loan Pricing Vs. Educational Qualifications

From the following table we can observe that the mean value of loan provision, profitability and banks capital was high for risk officer/analyst, high loan pricing was high for risk managers (Table 8).

\begin{tabular}{|c|c|c|c|}
\hline \multicolumn{2}{|c|}{ Designation } & Profitability & $\begin{array}{c}\text { Loan } \\
\text { pricing }\end{array}$ \\
\hline \multirow{4}{*}{ HEAD RISK } & Mean & 3.3611 & 3.1389 \\
\cline { 2 - 4 } & $\mathrm{N}$ & 18 & 18 \\
\cline { 2 - 4 } & $\begin{array}{c}\text { Std. } \\
\text { Deviation }\end{array}$ & .43065 & .55055 \\
\hline \multirow{3}{*}{ MANAGK } & Mean & 3.3553 & 3.2237 \\
\cline { 2 - 4 } & $\mathrm{N}$ & 38 & 38 \\
\cline { 2 - 4 } & $\begin{array}{c}\text { Std. } \\
\text { Deviation }\end{array}$ & .42566 & .54460 \\
\hline & Mean & 3.3868 & 2.9623 \\
\cline { 2 - 4 } & $\mathrm{N}$ & 53 & 53 \\
\hline
\end{tabular}

\begin{tabular}{|c|c|c|c|}
\hline $\begin{array}{c}\text { RISK } \\
\text { OFFICER / } \\
\text { ANALYST }\end{array}$ & $\begin{array}{c}\text { Std. } \\
\text { Deviation }\end{array}$ & .43181 & .52210 \\
\hline \multirow{3}{*}{ Total } & Mean & 3.3716 & 3.0826 \\
\cline { 2 - 4 } & $\mathrm{N}$ & 109 & 109 \\
\cline { 2 - 4 } & $\begin{array}{c}\text { Std. } \\
\text { Deviation }\end{array}$ & .42575 & .54333 \\
\hline
\end{tabular}

Table 8: Profitability and Loan Pricing Vs. Designation

\section{b) Hypothesis testing - ANOVA}

ANOVA is a data analysis method of great elegance, utility and flexibility. It is the most effective method available for analyzing the data from experiments (Armstrong at. al, 2000). ANOVA is a method of great complexity and subtlety with many different variations, each of which applies in a particular experimental context. Hence, it is possible to apply the wrong type of ANOVA in a particular experimental situation and, therefore, draw the wrong conclusions from the data. To test the hypotheses, ANOVA method used in this research. 


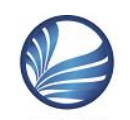

ELK

Asia Pacific Journals

$\underline{\text { www.elkjournals.com }}$

\section{Hypothesis 1}

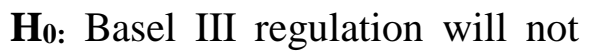
decrease banks' profitability in UAE.

$\mathbf{H}_{\mathrm{A}}$ : Basel III regulations will decrease banks' profitability in UAE.

In order to test whether there is a significant difference between the profitability in UAE and duration of implementation of Basel III regulations in UAE, an Analysis of variance was carried out by using SPSS (Table 9).

ANOVA -Profitability

\begin{tabular}{|c|c|c|c|c|c|}
\hline & $\begin{array}{l}\text { Sum of } \\
\text { Squares }\end{array}$ & df & $\begin{array}{l}\text { Mean } \\
\text { Square }\end{array}$ & $\mathrm{F}$ & Sig. \\
\hline $\begin{array}{l}\text { Between } \\
\text { Groups }\end{array}$ & 10.209 & 3 & 5.105 & 57.759 & .000 \\
\hline $\begin{array}{l}\text { Within } \\
\text { Groups }\end{array}$ & 9.368 & 106 & .088 & & \\
\hline Total & 19.577 & 109 & & & \\
\hline
\end{tabular}

Table $9-\mathrm{H} 1$

From the table above we can observe that the $\mathrm{F}$ value was 57.759 and its corresponding $\mathrm{p}$ value is $0.000<0.05$ between the profitability and duration of implementation of Basel III regulations. Hence, we can reject the null hypothesis and accept the alternate hypothesis.

\section{Hypothesis2}

Ho: Basel III regulation will not lead to a higher loan pricing in UAE

$\mathbf{H}_{\mathrm{A}}$ : Basel III regulation will lead to a higher loan pricing in UAE

In order to test whether there is a significant difference between the high loan pricing in UAE and duration of implementation of Basel III regulations in UAE, an Analysis of variance was carried out by using SPSS (Table 10).

ANOVA - High loan pricing

\begin{tabular}{|l|c|c|c|c|c|}
\hline & $\begin{array}{l}\text { Sum of } \\
\text { Squares }\end{array}$ & df & $\begin{array}{c}\text { Mean } \\
\text { Square }\end{array}$ & $\mathrm{F}$ & Sig. \\
\hline $\begin{array}{l}\text { Between } \\
\text { Groups }\end{array}$ & 8.119 & 3 & 4.059 & 18.108 & .000 \\
\hline
\end{tabular}




\begin{tabular}{|l|l|l|l|l|l|} 
Within & 23.763 & 106 & .224 & & \\
\hline Troups & & & & & \\
\hline
\end{tabular}

Table $10-\mathrm{H} 2$

From the table above we can observe that the $\mathrm{F}$ value was 18.108 and its corresponding $\mathrm{p}$ value is $0.000<0.05$ between the high loan pricing and duration of implementation of Basel III regulations. Hence, we can reject the null hypothesis and accept the alternate hypothesis.

\section{6) Conclusion and Suggestions for Further Study}

Basel III standards accepted as one of the best practice to safe guard the banking system globally. The overall result of this research show that; Basel III implementation has impact on banks profitability and loan pricing.

The hypotheses ANOVA test shows that; all the null hypotheses are rejected and all alternatives are accepted.
The result of research shows that, implementation of Basel III will lead to a higher loan pricing, and decrease profitability.

The results show that banking system in the UAE is aware of and have knowledge about the Basel III Accord and its' impact from capital management only. An interesting study to conduct would be to explore the impact of Basel III in following areas:

a) Impact of Basel III on liquidity risk and liquidity management in UAE banking;

b) Impact of Basel III on risk governance; and

c) Impact of Basel III on economic growth,

Lastly, we think it would be interesting to conduct a similar study as ours in a couple of years and post implementation of Basel III in order to see if the 


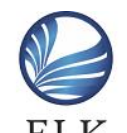

Asia Pacific Journals

www.elkjournals.com

respondents' perceived impact of the Basel III accord really occurred.

\section{References}

[1] Al Suwaidi. 2012, Basel III and UAE Banking System, http://www.gulfnews. com /business /banking/uae-banks-prepared-forbasel-iii-1.1 110871

[2] Al-Tamimi, H. 2012. Risk Management Practices: An Empirical Analysis of the UAE Commercial Banks. Finance India, Vol. XVI, No. 3, pp. 1045-1057

[3] Basel Committee on Banking Supervision. 2010, BCBS 179, The Basel committee's response to the financial crisis: Report to the G20, (p 1- 15)

[4] Cosimano, T. F. and Hakura .D, 2011, Bank Behavior in Response to Basel III: A Cross-Country Analysis?" IMF working paper WP/11/119,
[5] Elliott, D. J. 2009, "Quantifying the Effects on Lending

[6] Cortina, J.M. 1993. What is coefficient alpha? An examination of theory and applications" Journal of Applied Psychology 78, 98-104. dx.doi.org/10.1037/00219010.78.1.98

[7] Gulfnews, 2014, Basel III to improve asset quality and risk return profiles of ME banks, Http://gulfnews.com/business/banki ng/basel-iii-to-improve-assetquality-and-risk-return-profiles-ofme-banks-1.1420099

[8] KPMG. 2011, Basel III: Issues and Implications, http://www.kpmg.com /Global/en/ IssuesAndInsights/ArticlesPublicati ons/Documents/basell-III-issuesimplicatio ns.pdf

[9] Roy. D, 2014, Performance of the Indian Banking Sector in the Basel 
Asia Pacific Journals

$\underline{\text { www.elkjournals.com }}$

Regime, Indian Institute of

Management Indore.

[10] R. A. Armstrong, S. V. Slade, and F. Eperjesi. 2000, An introduction to analysis of variance (ANOVA) with special reference to data from clinical experiments in optometry. Ophthalmic and Physiological
Optics.

doi:10.1046/j.14751313.2000.00502.x

[11] Wignall .A.B., Atkinson. P, 2010, Thinking Beyond Basel III: Necessary Solutions for Capital and Liquidityll, OECD Journal: Financial Market Trends vol. 2010/1. 